\title{
A TV Rescanning Method with a Combination of CCTV Camera and a Small Computer
}

\author{
Masaomi TAKIZAWA \\ Division of Radiological Technology, Shinshu University Hospital, \\ Asahi 3-1-1, Matsumoto 390, Japan \\ Received April 23, 1973
}

\begin{abstract}
A simplified digital image processing of photoscintigrams was performed by data acquisition with CCTV re-scan and by data processing with a small computer. Scanned TV picture signals are sampled, digitalized, in sequence, and stored in the memory of the computer. Sampling pulses are generated by a time delay unit built in an oscilloscope. The timing of sampling pulses is controlled by the computer programs. Some of the fundamental characteristics of this method were examined by the use of a test chart. They were, a flatness of sensitivity and a linearity in gray scale of vidicon tube. When characteristics of a vidicon tube are measured, they could be compensated by computer processing. As the result of sampling, an image is divided into $70 \times 50$ or 3,500 points. After the compensation for a TV tube characteristics, various kinds of data processing were performed according to the diagnostic requirement.

Some of the result in the cases of thyroid and liver are presented. Digital image processing has much more flexibility than analog processing.
\end{abstract}

\section{Introduction}

As the result of remarkable increase in the number of nuclear medicine examinations, the necessity of efficient filing and image processing is increasing year by year.

Scintigrams, when they are converted into TV images, could be easily transmitted to any place and could be analyzed quantitatively by means of TV data processing devices. In this paper, the author introduced a simplified digital TV image processing system which is applicable to the data handling and analysis of scintigrams.

\section{Method and Materials}

The principle of the author's device for the TV data processing is shown in Fig. 1. Vertical synchronizing signals from the TV camera are fed to an analog to digital converter and trigger the sampling process. Horizontal synchronizing pulses, after certain steps of rate down according to the programmed interval for the vertical axis, are connected to the external trigger of an oscilloscope. Delayed pulses generated in the time delay unit of the oscilloscope are used as sampling signals for the horizontal axis. They trigger a wait instruction terminal of the computer, and drive the sample hold unit, at the same time. Thus, TV picture signal are sampled, read and stored in sequence. Sampling is executed at one point for each selected horizontal scan and for one frame. In the next frame, the position of sampling on the horizontal scan is slightly shifted, and the sampling is repeated. Thus, a two dimensional digital data acquisition is performed. The number of matrix was decided as 70 on horizontal axis, 50 on vertical axis and 3,500 in total.

At first, a flatness characteristics of vidicon tube was examined, a special view box was designed for this purpose. The flatness of light source was kept less than $10 \%$ deviation. The film-camera distance was kept at $50 \mathrm{~cm}$ and target and beam current of vidicon tube were kept at constant. Specifications of TV camera and computer for this method were shown in Table 1 . 


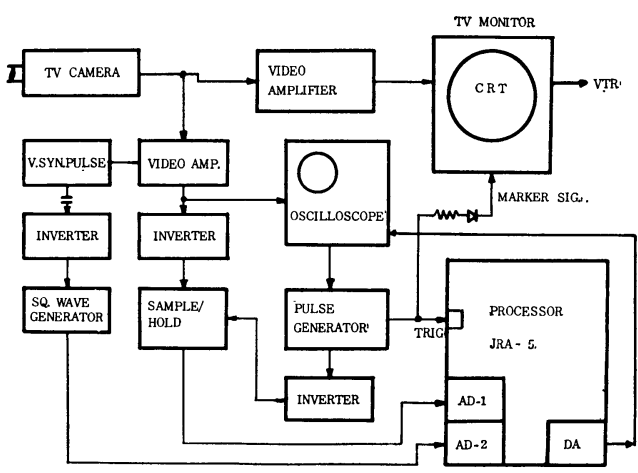

Fig. 1 Block diagram of processing system.
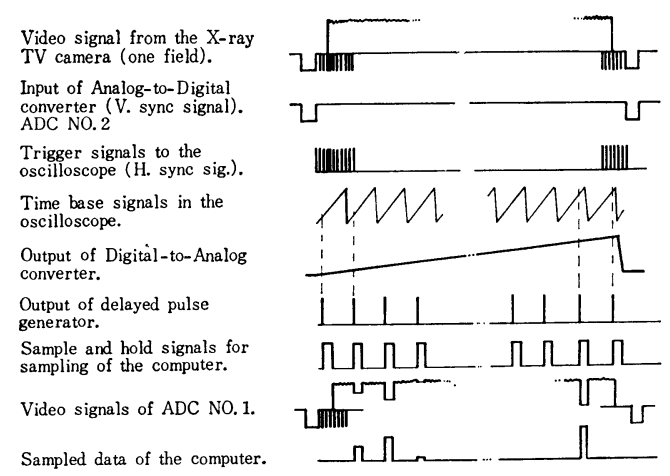

Fig. 2 Timing chart for sampling of the video signal.

Fig. 3a shows a characteristics of TV camera before corrections. The correction for the flatness characteristics of vidicon tube was performed by hard or sof $t$ wares. The procedure of correction is as follows. Data of TV camera characteristics as shown in Fig. 3a are stored in the upper 8 bits each word up to about 3,500 words. Scanned data of scintigram image are stored in the lower 8 bits each word. The latter data are divided by the former data and are given a corrected digital image. Fig. $3 b$ shows the flatness after the correction. Improvement of flatness is quiet remarkable as shown in this figure.

Next problem is a reproducibility of images. As regards this point, the TV camera used in this experiment showed fairly good quality, as shown in Fig. $4 a$ and $b$. Distortions were within allowable range. The third problem is a linearity in the gray
Table 1 Specifications of sampling and processing devices

$\begin{array}{ll}\text { A. Television camera } & \\ \text { Horizontal resolution } & 350 \text { lines (Center) } \\ \text { Vertical resolution } & 300 \text { lines (Center) } \\ \text { Frequency } & 1 \mathrm{kHz}-7 \mathrm{MHz} \\ \quad \text { characteristics } & \pm 3 \mathrm{~dB} \\ \text { Signal to noise ratio } & \text { up to } 38 \mathrm{~dB}\end{array}$

B. Computer

Memory capacity $\quad 4,096$ words

Cycle time

$5 \mu \mathrm{sec}$

Word length

16 bits

System

Input output device

stored program

Teletypewriter (ASR-33)

Photo tape reader 120 characters/sec

Paper tape puncher 30 characters/sec

Analog to digital converter (2 channel)

$\begin{array}{ll}\text { conversion time } & 4.5 \mu \mathrm{sec} \\ \text { full scale } & 100 \mathrm{mV}, 1 \mathrm{~V}, \text { and } 10 \mathrm{~V} \\ \text { accuracy } & \pm 0.5 \%\end{array}$

C. Sample and hold circuit

$\begin{array}{ll}\text { aperture time } & 0.1 \mu \mathrm{sec} \\ \text { acquisition time } & 3 \mu \mathrm{sec} \\ \text { full power resp. } & 500 \mathrm{kHz} \\ \text { accuracy } & \pm 0.1 \%\end{array}$

scale. Gray scale test was carried out by a following method. A film test chart for gray scale was prepared of density was 0.52.5 (Fig. 5a). Digitalized images of this gray scale before and after the correction is shown in Fig. 5b and Fig. 5c. The result shows that this system has a fairly good linearity in the limited range of density.

Since the images of scintigram are composed of multi photo pulse, a relationship between the number of pulses and density of film or of digitalized image should be considered. Fig. 6a shows a film which was exposed to pulse late from 12 to $150 \mathrm{cps}$ with constant scanning speed $1 \mathrm{~cm} / \mathrm{sec}$. Digitalized images after the correction are shown in Fig. 6b. The relationship between the pulse rate and the film density obtained from the data of $6 \mathrm{~b}$ is shown in Fig. 7. This result suggests that certain correction should be done by a sof $t$ ware according to the pulse 


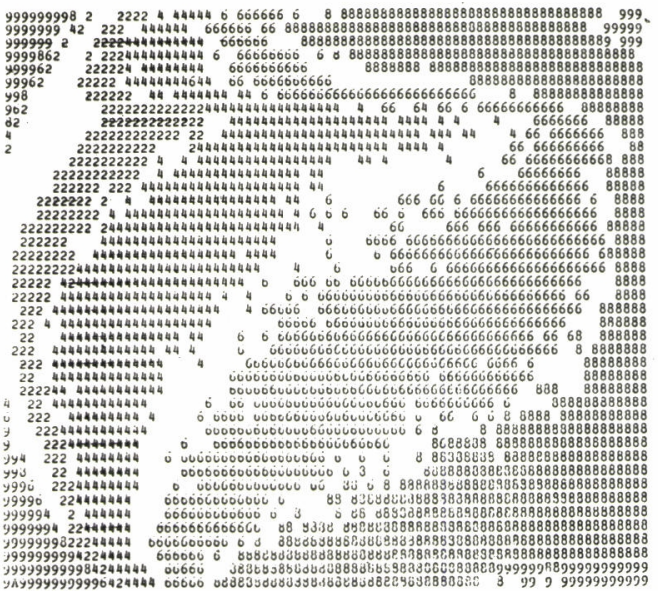

3 a Original flatness data which were displayed by typewriter codes, character shows percentage of video signal amplitude.

Fig. 3 Compensation of flatness characteristics of the vidicon camera.

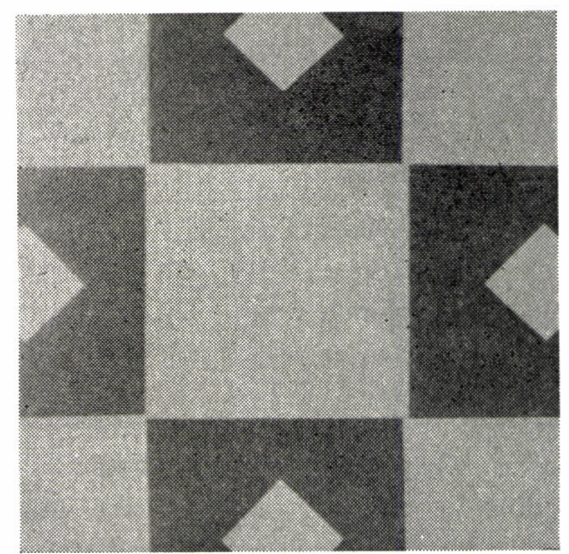

4 a Original test pattern is made by plastic, lead plate and X-ray exposure.

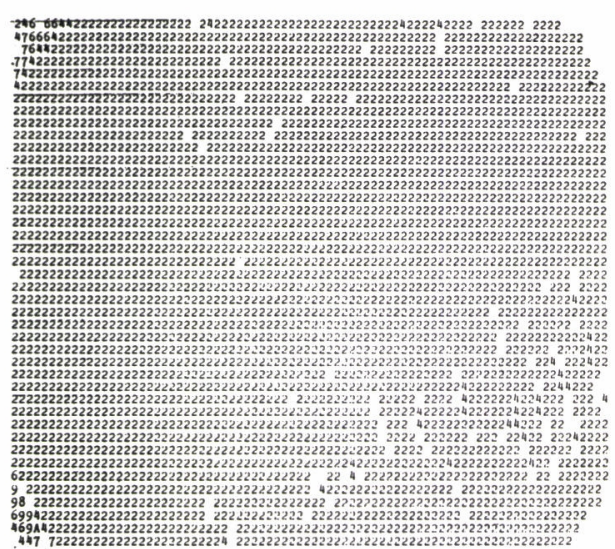

$3 \mathrm{~b}$ After the compensation by the correction data.

Fig. 4 Test of reproducibility of the TV picture.

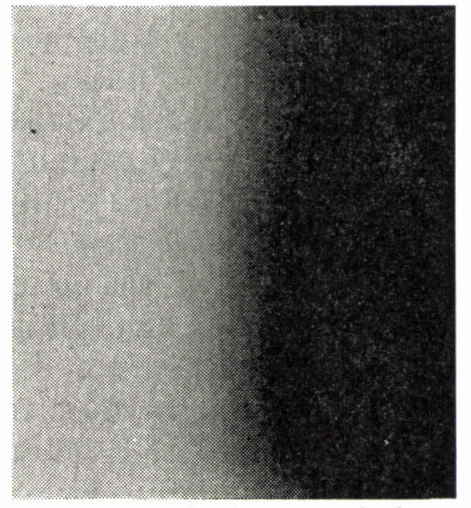

5 a Original film is made by 5 $\mathrm{mm}$ steps acrylite phantom and X-ray films.

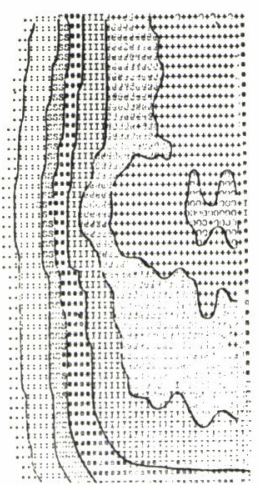

$5 \mathrm{~b}$ Before the compensation, display is done by numeric codes of $10 \%$ step.

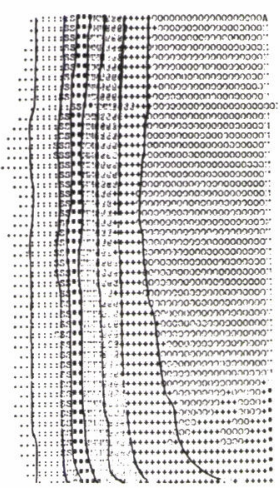

5 c Digital image after the compensation.

Fig. 5 Compensation of linearity of the density scales. 


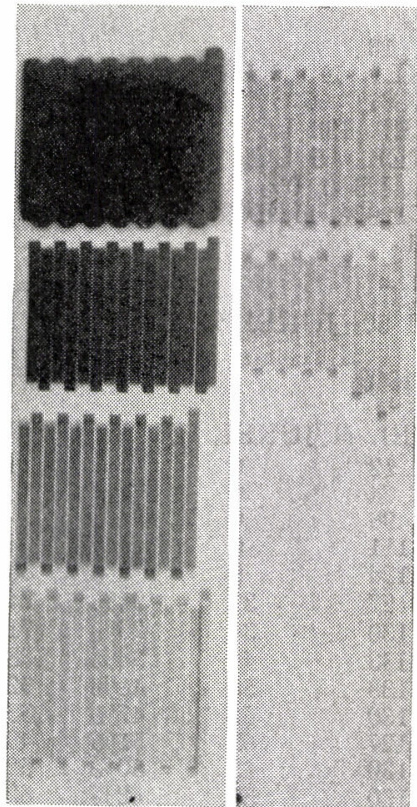

6 a A film shows record of each pulse rate by the scanning.

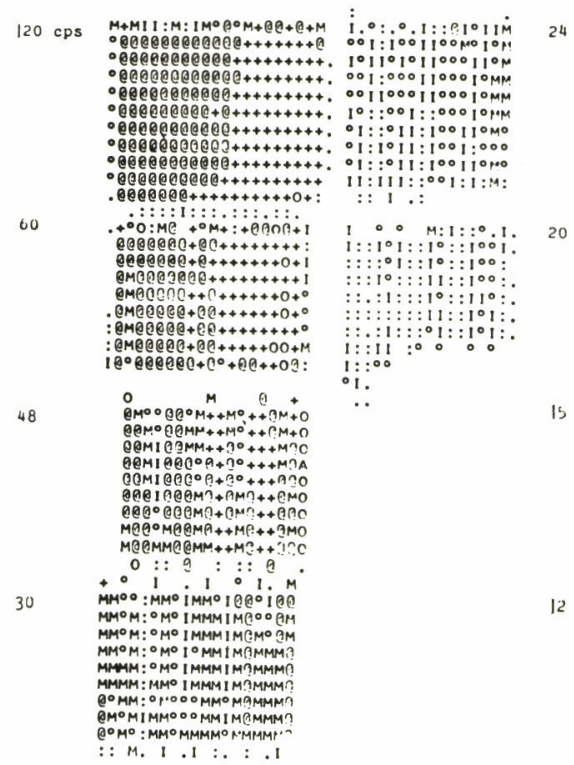

$6 \mathrm{~b}$ Digital image.

Fig. 6 Calibration for density on the film and pulse density of the scanner.

rate or film density. Data acquisition time depends on the number of sampling points on a horizontal scan line. Since the sampling was done at the rate of one sampling point for every one horizontal scan, the rate of data aquisition is 60 point per second. The total length of data acquisition is given as number of sampling points. About two seconds are necessary for the computing process for the flatness correction. Examples of the

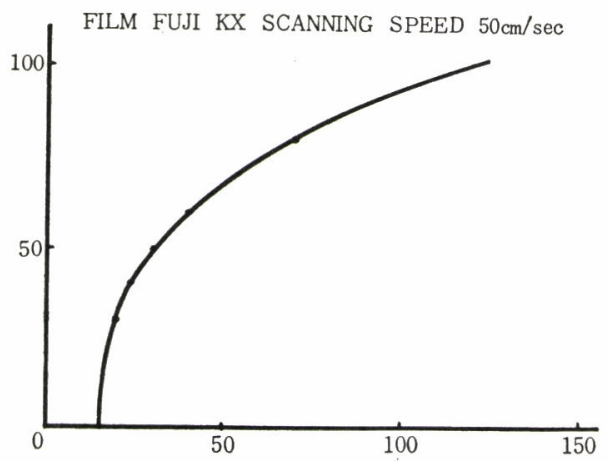

Fig. 7 The curve shows a characteristics of the pulse rate and digital levels of the computer.

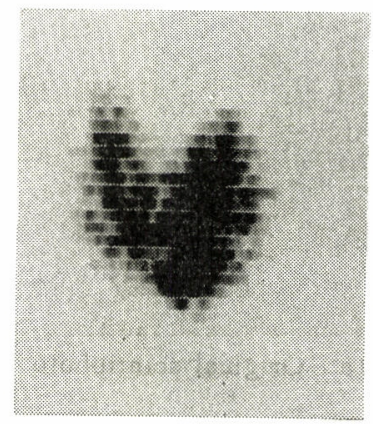

8 a Thyroid scintiphoto.

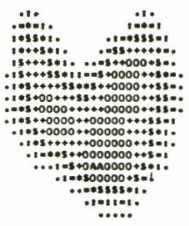

$8 \mathrm{~b}$ Digital image is displayed by 8 gray scales on the tele-typewriter.

Fig. 8 Case 1. 


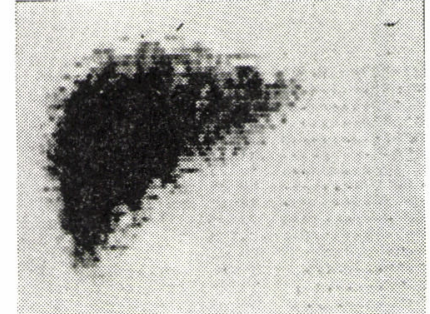

9 a Liver scintiphoto.

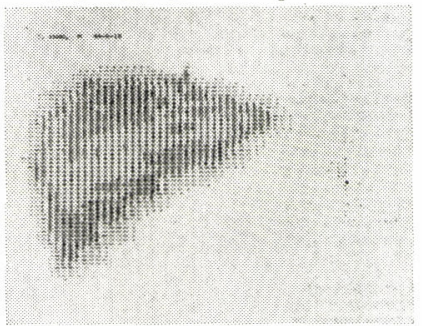

$9 \mathrm{~b}$ Digital image with smoothing, display conditions are the same as Fig. 8b.

Fig. 9 Case 2.

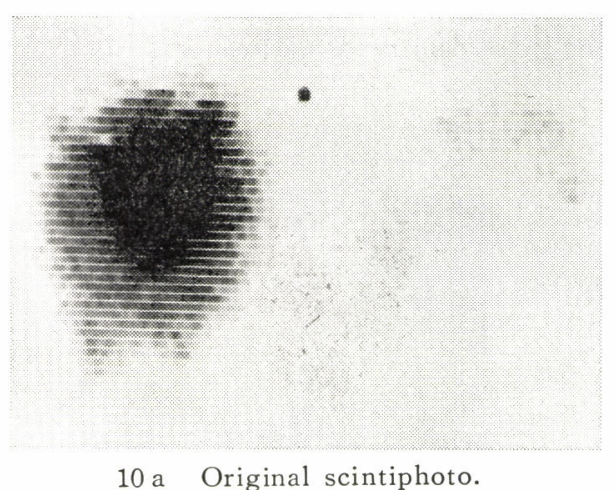

10 a Original scintiphoto.
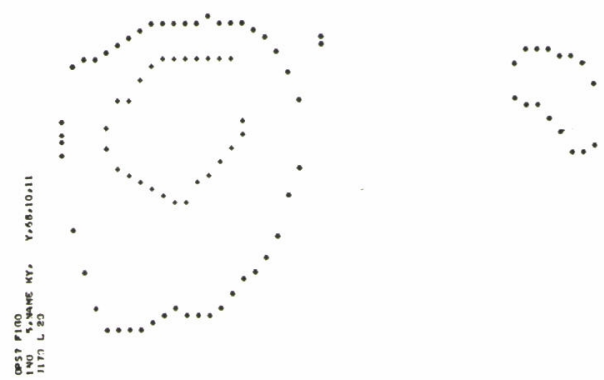

$10 \mathrm{~b}$ Digital image is displayed as two iso-density scales of 20 and $80 \%$.

Fig. 10 Case 3, Automatic analysis of each liver parameter by the small computer.
LIVER

DLOC 13

L OUKEI 110 S 134

$\mathrm{H}$ OUKEI $65 \mathrm{~S} \quad 32, \mathrm{H} / \mathrm{L} \quad 23 \%$

L JUKEI 133 LOC 13

H JUKEI 65 LOC 11

RS 134, LS 0, 0\%

$\mathrm{LJ} / \mathrm{LO} 120 \%, \mathrm{H} 100 \%$

DEF 1

\section{SPLEEN}

OUKEI 50, JUKEI 43, S 14

\section{SP/LI $10 \%$}

L JUKEI, H JUKEI, H/L \%, LOW, UP, DEF

$\begin{array}{rrrrrr}12 & 0 & & & & \\ 74 & 0 & & & & \\ 96 & 0 & & & & \\ 111 & 0 & & & & \\ 124 & 9 & 7 \% & 83 & 31 & 0 \\ 127 & 31 & 24 \% & 74 & 21 & 0 \\ 130 & 34 & 26 \% & 71 & 24 & 0 \\ 133 & 46 & 34 \% & 68 & 18 & 0 \\ 133 & 55 & 41 \% & 62 & 15 & 0 \\ 130 & 62 & 47 \% & 55 & 12 & 0 \\ 127 & 65 & 51 \% & 49 & 12 & 0 \\ 130 & 65 & 50 \% & 52 & 12 & 0 \\ 130 & 55 & 42 \% & 62 & 12 & 0 \\ 133 & 52 & 39 \% & 65 & 15 & 0 \\ 127 & 46 & 36 \% & 68 & 12 & 0 \\ 120 & 40 & 33 \% & 68 & 12 & 0 \\ 114 & 6 & 5 \% & 68 & 40 & 0\end{array}$


application of this method for the re-scanning of scintigrams are shown in Figs. $8 \sim 10$. Various kinds of data processing were realized by using these digitalized image data.

In the case of liver and spleen scan, the following parameters are computed and estimated at iso-contour lines of Fig. 10c; area, diameter, location of maximum density, liver and spleen area ratio, and so on. Fig. 10c shows a contour plot of isodensity levels corresponding to $20 \%$ and $80 \%$ density respectively.

\section{Discussion}

Quantitative image analysis of scintigrams is important for the purpose of better interpretation of the scan. Rescanning of scintigrams, in the past, was only on the basis of quantitative or visual conversion. Computer processed TV digital rescanning method developped by the author have greatly improved the accuracy of quantitative analysis of radioisotope images. The merits of the method are summarized as follows. 1) Quantitative evaluation of scintigrams. 2) High speed rescanning. 3) Applicability to the filing retrieval and transmission of scintigrams.

Several technical problems to relating to the digital image acquisition and processing have to be studied. In this paper, the author shows that most problem could be solved by the combination of adequate hard and soft wares. In future, the TV system will be widely used for the purpose of medical image processing including the field of nuclear medicine. Data processing after the acquisition using TV system can be processed by a various sign of the computer system. In the case of scintigram images, on account of their relatively smaller number of picture elements, a mini-computer with about $4 \mathrm{k}$ memory can be used efficiently. Further data processing on the digitalized data will extract many useful informations, and contribute greatly to the medical diagnosis.

\section{Acknowledgment}

The author wishes to thank Prof. T. Kobayashi and Prof. Y. Umegaki for continuous encouragement and valuable advice.

This research was supported by the research grant of Ministry of Health and Welfare in $1971 / 1972$.

\section{References}

1) Asahina, K.: Application of the VTR to RI data processings, Eizojoho, 10 (1971)

2) Brown, D.W.: Digital computer analysis and display of the radioisotope scanning, J. Nucl. Med., 5, 802 6 (1964)

3) Bruno, F.P., et al.: A digital computer data acquisition, display and analysis for the gamma camera, Radiology, 96, 658 61 (1970)

4) Iinuma, T.: Application of digital technique to radioisotope imaging, Jap. J. Med. Electron. Biol. Eng., 7, 269 80 (1969)

5) Rosenthall, L.: Application of the direct-store video tape data processor, Jap. J. Nucl. Med., 7, 220 (1970)

6) Kojima, K. and Hisada, K.: Consideration of the optimum memory capacities for storage, and number of points for display of scintillation camera images, Radioisotopes, 21, 32 37 (1972)

7) Takizawa, M.: Sampling and processings for liver scintigram using a CCTV and a small computer, Nipp. Act. Radiol., 31, 655 9 (1971) 
要 旨

TV カメラと小型 Computer を用いた RI Scintiphoto の digital re-scan 法

槞 沢 正 臣

信州大学医学部附属病院中央放射線部 RI 診療部門

工業用 TV カメラと, 小型 computer を用いた， RI フォトシンチグラムのディジタルリスキ ヤン法が試みられた。均一な面光源によって撮像された TV カメラの映像信号は，オシロスコーI プを用いた簡易なインターフェースによってサンプリングされる。オシロスコープ時間軸によって, data とすべき走査線の幅が決められ，また computer DA 変換器からの 8 ビットの電圧により， RI 像のサンプリング点が決められ，掃引される。digital matrix の大きさは $70 \times 50(3,500)$ ポ イントである。TVカメラのるつ各種歪の補正が検討されたのち, 甲状腺, 肝シンチフォトのリス キャンが試みられ，また肝 RI 像の自動計測を実施できる可能性が示された。 